\title{
SUFI APPROACHES TO EDUCATION: THE EPISTEMOLOGY OF IMAM AL-GHAZALI
}

\author{
Muhammad Yusuf Fadhil ${ }^{1}$, Saliha Sebgag ${ }^{2}$ \\ Universitas Airlangga Surabaya, Indonesia ${ }^{1}$ \\ Deparment of Letters and Arabic Language, University Mohamed Khider of Biskra, Algeria ${ }^{2}$ \\ muhammad.yusuf.fadhil-2016@psikologi.unair.ac.id
}

Received: 18-08-2020 Revised: 17-10-2020 Accepted: 18-12-2020

\begin{abstract}
The goal of this paper is to explore the sufi pedagogy that aims to inculcate devout worship and happiness amongst students. Methodologically, this research is qualitative in nature and focuses on the literature of Imam Al-Ghazali. After the data has been collected, the material results are presented systematically with an epistemological analysis. The conclusions of this paper are as follows: ontologically speaking, science is not an abstraction of the object being observed, but the essence of knowledge is a divine light that radiates to the soul (al-ruh ilahiyah) that exists in all bumans. Epistemologically, knowledge can be obtained through the optimization of reason. Hence, the mujahadah and the riyadhah are tasks that must be undertaken by students in order to secure the knowledge of mukasyafah. In terms of axiology, knowledge is a means to get closer to Allah, to gain happiness in the world and the hereafter. That is why the profile of the learning outcome of sufi education is ulama' akbirat; namely scholars who have the following characteristics; 'abid, zabid, 'alim, faqih and mukblish.
\end{abstract}

Keywords: Sufi education, Epistemology, Ontology, 'ilm al-Mukasyafah.

\begin{abstract}
Abstrak
Artikel ini bertujuan untuk menjelaskan konsep pendidikan sufistik bagi murid; sebuah konsep pendidikan yang bertujuan agar murid menjadi hamba Allah yang taat beribadah untuk memperoleh kebahagian dunia dan akhirat. Secara metodologis, penelitian ini adalah penelitian kualitatif yang terfokus pada literatur atau karya yang ditulis oleh Imam Al-Ghazali. Setelah data terkumpul, kemudian data disajikan secara sistematis dan selanjutnya dianalisis dengan perspektif filasat ilmu (analisis epistemologis). Temuan dari pembahasan ini adalah secara ontologis, ilmu bukan abtraksi objek yang diamati, akan tetapi hakekat ilmu adalah cahaya ilahiyah yang memancar kedalam hati yang suci. Ilmu adalah sifat Allah sehingga semua ilmu adalah terpuji. Karena ilmu pula, ilmu harus menjadi energi bagi murid untuk berbuat baik dan terpuji. Secara epistemologis, ilmu dapat diperoleh melalui optimalisasi akal. Bagi beliau, optimalisasi akal merupakan proses persiapan untuk memperoleh ilmu, sebab hakekat ilmu manusia adalah hasil illuminasi cahaya Allah. Melalui jalan mujabadah dan riyadhab murid akan dianugrahi ilmu mukasyafah. Dari segi aksiologinya, ilmu merupakan sarana untuk mendekatkan diri kepada Allah untuk memperoleh kebahagian dunia dan akhirat. Karena itulah profil learning outcome pendidikan sufistik adalah ulama' akbirat, yaitu ulama' yang bersifat 'abid, rabid,'alim, faqih, dan mukblish.
\end{abstract}

Kata Kunci: Pendidikan sufistik, Epistemologi, Ontology, 'ilm al-Mukasyafah. 


\section{INTRODUCTION}

The ideal education according to Sufi perspectives is one that inculcates happiness in both the material world and the hereafter amongst students. Worldly bliss is not the main goal of Sufi education, it is only a means for achieving happiness in the hereafter. To obtain happiness, two things are needed: namely true faith (iman) and righteous deeds ('amal shalih). ${ }^{2}$ Al-Qur'an often cites both faith and good deeds in the same places. It indicates a close relationship between both (iman and 'amal shalib). According to the Sufi educational paradigm, there is no separation between aspects of cognitive, affective and psychomotor skills ${ }^{3}$. These three are united in one feature ${ }^{4}$. Knowledge ( $\left.{ }^{(i / m}\right)$ is the main core, the mental condition/affection ( $a l-b a l$ ) is the essence, while the skill to do righteous deeds ('amal shalih) is the result or fruit. ${ }^{5}$ This is the meaning of the Arabic axiom that knowledge without action is like a tree without fruit (al-ilm bila 'amal ka al-sajar bila tsamar). For Imam Al-Ghazali, knowledge is also closely related to belief in one deity or tawhid. This is the reason why the Arabic term al-ilm can also mean unity (tawhid), because true knowledge will bring about true fear of Allah, and then this fear will bear fruitful deeds. ${ }^{6}$

Ontologically, knowledge according to Sufi perspectives are not a collection of perceptions or an abstraction of an object in the human mind. Rather, it is the illumination of reflected divine light into the core of the human soul (qalb); namely lathifah rubaniyah rubaniyah (a subtle entity that is spiritual and divine). Divine light (knowledge) can be obtained through learning (ta'allum): optimizing the ability of reason ${ }^{7}$, and also through purification of the soul (mujahadah and riyadhah). In al-Qur'an, surah al-Ankabut, verse: 69, Allah promises to those who are sincere guidance on the paths (knowledge) towards His pleasure. ${ }^{8}$ Through both mijabadah and riyadhah, the heart becomes clean and healthy so that the heart is ready to receive the illumination of knowledge from Allah. Illuminative science cannot go wrong. There is no doubt in this knowledge.'

1 Ali Aslan Guemuesay, "Boundaries and knowledge in a Sufi Dhikr Circle," Journal of Management Development 31, no. 10 (19 Oktober 2012): 1077-89, https://doi.org/10.1108/02621711211281861; Ririn Afrian Sulistyawati, Probosuseno, dan Sri Setiyarini, "Dhikr Therapy for Reducing Anxiety in Cancer Patients," AsiaPacific Journal of Oncology Nursing 6, no. 4 (2019): 411-16, https://doi.org/10.4103/apjon.apjon_33_19; Ziaulhaq Hidayat dan Muzakkir Syahrul, "Indonesian Sufi in Malay World: A Preliminary Exploration with Reference to Tariqa Naqshbandiyya-Khalidiyya Babussalam (Tnkb)," Journal of Indonesian Islam 11, no. 1 (9 Juli 2017): 201-222222, https://doi.org/10.15642/JIIS.2017.11.1.201-222.

2 Al-Qur'an Surah al-Kahfi, verse 110.

3 Masthurhah Ismail, Puteri Rohani Megat Abdul Rahim, dan Muhammad Sufi Mohamad Yusoff, "Educational Strategies to Develop Discipline among Students from the Islamic Perspectives," Procedia - Social and Behavioral Sciences, The Proceedings of the 1st Evaluation of Learning for Performance Improvement International Conference 2013, 107 (11 Desember 2013): 80-87, https://doi.org/10.1016/j.sbspro.2013.12.402.

${ }^{4}$ Charles. Lindholm, "Islam: Middle East," dalam International Encyclopedia of the Social \& Behavioral Sciences (Second Edition), ed. oleh James D. Wright (Oxford: Elsevier, 2015), 731-36, https://doi.org/10.1016/B978-0-08097086-8.84014-3.

5 Al-Ghazali, Ibya' Ulum al-Din, vol. 8 (Arab Saudi: Dar al-Minhaj, 2011), 247.

${ }^{6}$ Al-Ghazali, Ihya' Ulum al-Din, vol. 1 (Beirut: Dar al-Fikri, t.t.), 45-46.

7 Al-Bukhori, Shabih al-Bukhori, vol. 1 (Beirut: Dar al-Fikri, 1981), 25.

8 Al-Ghazali, Ibya' Ulum al-Din, vol. 3 (Beirut: Dar al-Fikri, t.t.), 26.

${ }^{9}$ Al-Ghazali, Ibya' Ulum al-Din, t.t., 1:31. 
Sufi education for students is a process of transforming knowledge of attitudes and behaviors to mature humans into complete human beings. ${ }^{10}$ Such an educational model is relevant to the goal of National Education, according to Law Number 20 of 2003, concerning the National Education System. ${ }^{11}$ Etymologically, Sufi education comes from two words, namely the word Sufi and the word education. Terminologically, education is a conscious and planned effort to create an atmosphere of learning and the learning process so that students actively develop their potential to have religious-spiritual strength, self-control, personality, intelligence, and noble morals ${ }^{12}$. Meanwhile, the word Sufi is the adjective of Sufi (namely the actor of Sufism). So Sufi education is a conscious and planned effort made by Sufis to create graduates who have noble morals ${ }^{13}$. Abu Hasf al-Haddad stated that all the teachings of Sufism are 'adab (noble morals); whoever can be civilized permanently in all his conditions will attain a degree of proximity to Allah. ${ }^{14}$

Epistemologically, the concept of Sufi education for students is one that explains how a student can acquire two kinds of knowledge: 'ilm al-mukasyafah and ilm al-mu'amalah. Knowledge of al-mukasyafah is knowledge illuminated from God as a gift toward His servant. This becomes the culmination of all knowledge. ${ }^{15}$ This knowledge cannot possibly be described utilizing any words or language; this knowledge is only spoken of with signs, ${ }^{16}$ because this knowledge is secret, so it is unethical to talk about it in general. The al-Arif said: to reveal the secrets of divine qualities is disbelief $(k u f r) .{ }^{17}$ Meanwhile, the science of almu'amalab is the knowledge that explains the various conditions of the heart and its purification strategies. ${ }^{18}$ After the heart becomes pure, then the Sufi adept obtains knowledge of al-mukasyafah; and the peak of knowledge of al-mukasyafab is ma'rifat to Allah SWT. ${ }^{19}$ The discussion of this article is significantly different from the corpus of Rubaidi ${ }^{20}$, Hanani ${ }^{21}$, and Alwizar $^{22}$. This article will discuss the concept of Sufi education for students with an epistemological analysis according to al Ghazali; therefore, the paper focuses on discussing the

10 Ibnu Rusydi, "Paradigma Pendidikan Agama Integratif-Transformatif," Jurnal Pendidikan Islam 1, no. 1 (2011): 105-20, https://doi.org/10.14421/ipi.2011.11.105-120.

${ }_{11}$ Mohammad Ali, Imu dan Aplikasi Pendidikan (Bandung: Pedagogiana Press, 2007), 1.

12 Sobhi Rayan, "The Stage-Beyond-the-Intellect as a Method of Research in al-Ghazali's Theory," Medieval Mystical Theology 22, no. 1 (1 Juni 2013): 59-73, https://doi.org/10.1179/2046572613Z.0000000004; Mohammad Attaran, "Moral Education, Habituation, and Divine Assistance in View of Ghazali," Journal of Research on Christian Education 24, no. 1 (2 Januari 2015): 43-51, https://doi.org/10.1080/10656219.2015.1008083.

13 Keyvan Bolandhematan, "Spiritual Education in Islamic Tradition: Revisiting Ghazali's 'Deliverance," Religious Education 114, no. 2 (15 Maret 2019): 110-29, https://doi.org/10.1080/00344087.2018.1560585.

${ }^{14}$ Muhammad Syatha Al-Dimyathi, Kifayat al-Atqiya' wa Minhaj al-Ashfiya' (Semarang: Thoha Putra, t.t.), 25.

15 Al-Ghazali, Ihya' Ulum al-Din, t.t., 1:33.

16 Al-Ghazali, 1:14.

17 Al-Ghazali, Ibya' Ulum al-Din, vol. 4 (Beirut: Dar al-Fikri, t.t.), 257.

18 Al-Ghazali, Ihya' Ulum al-Din, vol. 1 (Arab Saudi: Dar al-Minhaj, 2011), 79.

19 Al-Ghazali, Ihya' Ulum al-Din, t.t., 1:71.

20 Rubaidi Rubaidi, "Pengarusutamaan Nilai-Nilai Sufisme dalam Pendidikan Islam Indonesia Kontemporer," Jurnal Pendidikan Agama Islam (Journal of Islamic Education Studies) 8, no. 1 (31 Juli 2020): 21-38, https://doi.org/10.15642/jpai.2020.8.1.21-38.

${ }^{21}$ Ahmad Hanani dan Nur Hamidi, “Tasawuf Pendidikan: Dari Spiritualitas Manusia Menuju Insan Kamil," Jurnal Pendidikan Agama Islam 16, no. 1 (5 Juni 2019): 35-62, https://doi.org/10.14421/jpai.2019.161-03.

22 Alwizar Alwizar, "Pemikiran Pendidikan Al-Ghazali," Potensia: Jurnal Kependidikan Islam 1, no. 1 (2 Juni 2015): 129-49. 
essence of knowledge according to Al-Ghazali, how a student acquires this knowledge, and what the ultimate goal is in seeking this. ${ }^{23}$

\section{METHOD}

This research is a qualitative literature review because the data related to this theme concentrates on the ideas of Imam Al-Ghazali and these cannot be calculated quantitatively. The data of Al-Ghazali's Sufi education are contained in his corpus. ${ }^{24}$ The primary data sources of this research are Kitab al-ilmi, the book of 'Ajaib al-Qalb, and the book of Riyadhiyat al-Nafs which were compiled in the book Ihya 'Ulum al-Din. Besides the works mentioned, alMunqidh Min al-Dhalal and also Misykat al-Anwar of Al-Ghazali are also the main references here.

Kitab al-Munqidh min al-Dhalal is the primary text with which to analyze the concept of science in the literature of Imam Al-Ghazali because in this book he expresses his doubts about empiricism and rationalism. Al-Ghazali follows these concerns with a scientific solution. Kitab al-ilm is also an axiomatic reference point in reconstructing the thoughts of Imam Al-Ghazali related to the concept of science, both ontology and axiology. Meanwhile, kitab Syarakh 'Ajaib al-Qalb explore the idea of the heart as a place for knowledge. Kitab Riyadbiyat al-nafs elucidates the strategy of purifying the soul in preparation for gaining knowledge. Kitab Misykat al-Anwar becomes a reference that explains how divine light (knowledge) and its levels shine into the human soul. Further, this book also contains an explanation of how this light can shine in the human heart.

This study uses content analysis through the following stages: ${ }^{25}$ (a) data reduction: all primary sources are read, then irrelevant material is discarded, then the remaining information is organized and compiled so that the discussion focuses on the problem under study; (b) display data: at this stage, the text written in the book is presented following its type, then it is presented systematically so that it is easy to understand; (c) in analyzing this concept, the writer uses epistemological analysis. Mohammad Adib states that the main conundrum in epistemology is comprehending what the essence of science is, how to obtain it, and what its purpose is. ${ }^{26}$ Therefore, the analysis in this paper focuses on this question, (d) conclusion: at this stage, the main issue for which this paper is written is answered clearly: namely the Sufi educational paradigm for students according to Al-Ghazali.

\footnotetext{
${ }^{23}$ In terms of focus, the discussion of this article is a further discussion of articles such as articles written by Muhammad Edi Kurnanto, "Pendidikan Dalam Pemikiran Al-Ghazali," Khatulistiwa 1, no. 2 (1 September 2011), https://jurnaliainpontianak.or.id/index.php/khatulistiwa/article/view/189; Zulkifli Agus, "Pendidikan Islam Dalam Perspektif Al-Ghazali," Raudhah Proud To Be Professionals: Jurnal Tarbiyah Islamiyah 3, no. 2 (17 Desember 2018): 21-38, https://doi.org/10.48094/raudhah.v3i2.28; Roziq Syaifudin, "Epistemologi Pendidikan Islam Dalam Kacamata Al-Ghazali Dan Fazlur Rahman," Epistemé: Jurnal Pengembangan Ilmu Keislaman 8, no. 2 (7 Desember 2013): 323-46, https://doi.org/10.21274/epis.2013.8.2.323-346.

24 Anton Bakker dan Achmad Charris Zubair, Metodologi Penelitian Filsafat (Yogyakarta: Kanisius, 1994), 24.

25 Heribertus Sutopo, Pengantar Penelitian Kualitatif: Dasar-Dasar Teoritis dan Praktis (Surakarta: Pusat Penelitian Universitas Sebelas Maret, 1988), 34-36.

26 Mohammad Adib, Filsafat Ilmu: Ontologi, Epistemologi, Aksiologi, dan Logika Ilmu Pengetahuan, 2 ed. (Yogyakarta: Pustaka Pelajar, 2010), 76.
} 


\section{SUFI EDUCATION CONCEPT FOR STUDENTS ACCORDING TO IMAM AL- GHAZALI}

Al-Ghazali's full name is Abu Hamid Muhammad Bin Muhammad al GhazaliathThusiasy-Shafi'i (born in Thus; 1058/450 H - died in Thus; 1111/14 Jumadil Akhir 505 AH; age $52-53$ years). Al-Ghazali's father died when he was a child and he was entrusted to his father's friend to be educated in religious knowledge. Al-Ghazali continued his education at the madrasah and studied jurisprudence under Sheikh Ahmad bin Muhammad ar-Radzakani in the city of Thusi. Then he went to Jurjan for study under Imam Abu Nashr al-Isma'ili. Next, he went to the city of Naisabur and studied under Imam Haramain al-Juwaini. Finally, Imam Al-Ghazali successfully mastered various branches of religious knowledge, such asShafi'i and khilafiyah jurisprudence, ushul, manthiq and philosophy. ${ }^{27}$ After Imam Haramain died, Imam Ghazali taught at Baghdad's an-Nidzamiyah madrasah and even became a senior leader at the institution.

Imam Al-Ghazali is a philosopher, jurist, theologian, and teacher in Islamic education. After becoming a famous scientist, Al-Ghazali experienced a period of doubt (syak) on his knowledge of the truth regarding physics and science. Placing reason in a high position trapped Al-Ghazali in personal and professional doubts due to the gap between the information received by the senses and the empirical reality ${ }^{28}$. His concerns were motivated by the limitations of the five senses in capturing and understanding this empirical reality. He also doubted the accuracy of the ratio in understanding reality. His skepticism is methodological, in which he postpones judgments and conclusions of the truth. Al-Ghazali denied all the knowledge he had acquired except the basic religious beliefs, namely knowledge of God, the Messenger of Allah, and the day after, which were so deeply rooted in him that they could not be shaken. So, he planned to go on Hajj as a way to calm himself down. In the year, $489 \mathrm{AH}$, he left Baghdad and headed to Shyam and joined the Zahids and Sufis for improving his spiritual development and purifying the soul. ${ }^{29}$ After several years of exile, Imam Al-Ghazali went to Makkah for Hajj. Finally, Al-Ghazali obtained what he believed to be the truth - and inner knowledge gained through the purification of his soul. ${ }^{30}$ In the $499 \mathrm{H}$, he returned to Nishabur to teach.

Imam Al-Ghazali was a successful educator and after the period of 'uqlab he returned to teach again in his birthplace until the end of his life. Al-Ghazali is widely known as a philosopher because he wrote the books of Maqashid al-Falasifah and Tahafut al-Falasifah. The first book is a summary of the opinions of preceding philosophers, while the second book is an attack on the perceived failings of said philosophers. According to him, most philosophers became infidels firstly because they believed that Allah's knowledge is universal so that Allah does not need to know the object partially. Secondly, according to most

27 Adz-Dzahabi, Siyar A'lam Nubala', vol. 19 (Beirut: Mu'asasah ar-Risalah, 2011), 323; Tajuddin 'Abdul Wahab As-Subki, Thabaqat asy-Syafi'iyah Kubro, vol. 6 (Beirut: Darul Kutub Ilmiyah, t.t.), 191.

28 Moshe Sokolow, "Knowledge and Action, Reason and Habit, in Jewish and Muslim Philosophies of Education," Journal of Research on Christian Education 22, no. 1 (1 Januari 2013): 21-29, https://doi.org/10.1080/10656219.2013.768104.

${ }_{29}$ Abdul Aziz Izzu Al-Din As-Sarwani, Muqaddimah Misykat al-Anwar wa Mashafat al-Anwar (Beirut: Alam alKutub, t.t.), 18-19.

30 Al-Ghazali's journey related to epistemological doubt and the answer shown in Al-Ghazali, Al-Munqidz. min al-Dhalal (Egypt: Ali Shabib wa Auladuh, 1952). 
philosophers nature is eternal (qadim). Thirdly, he objected to the belief that resurrection was only spiritual and not bodily. These three reasons led to the fact that philosophy became an act of infidelity (kafir). Imam Al-Ghazali is also known as a very influential Sufi figure. His book Ibya 'Ulum al-Din is a magnum opus of Sufism which is very well known in the Islamic world.

\section{THE CONCEPT OF EDUCATION ACCORDING TO IMAM AL-GHAZALI}

According to the results of the world Islamic education congress in Islamabad in 1980, Islamic education must be directed at the balanced growth of all aspects of student personality through spiritual training, intellectual intelligence, feelings, and senses. ${ }^{31}$ In line with the formulation of the congress mentioned above, an Egyptian Islamic education expert, Athiyah al-Abrasyi stated that the ultimate objective of Islamic education is to formulate noble morals in the personality of students. ${ }^{32}$ In general, the goals of Islamic education are reflected in the aims and methodologies of national education. According to the education law number 20 of 2003, the purpose of national education is to develop the potential of students to become human beings who are faithful, cautious, noble, healthy, creative, and independent. ${ }^{33}$

For Imam Al-Ghazali the primary goal of education was for students to secure lasting and true happiness. Secondly, students have to be close to Allah. These two aspects belong to scholars of the hereafter (ulama' al-akbirah) who have the following specific characteristics: they are ulama' who do not use knowledge as a tool to seek worldly gain. They are more concerned with the benefits of the hereafter because they know and believe that such spiritual objectives are more important than the world. They do not use knowledge to gain glory or a worldly position, because they realize that this will distance them far from Allah. They are focused on learning knowledge that can encourage religious behavior. They are not luxurious in food, drink, clothing, etc. They are independent scholars who cannot be influenced by the authorities. They are more concerned with the knowledge to maintain a pure heart. Their knowledge can preserve and strengthen beliefs about religious truth. ${ }^{34}$ From the above elaboration, it is known that education for students is not only a process of transferring knowledge from teachers to students. The ultimate goal is to form student personality around adherence to religious teachings and inculcate nobility of character in order to achieve true happiness ${ }^{35}$.

To achieve the desired ideals and profile goals, both students and teachers must have good ethics and character. According to Imam Al-Ghazali, knowledge is not just a collection

31 Imam Moedjiono, “Konsep Pendidikan Islam: Telaah Pemikiran Pendidikan Mohammad Natsir,” ElTarbawi 0, no. VI (2003): 46-61; Muhammad Zaim, “Tujuan Pendidikan Perspektif Al-Qur'an Dan Hadits (Isu Dan Strategi Pengembangan Pendidikan Islam)," Muslim Heritage 4, no. 2 (30 Desember 2019), https://doi.org/10.21154/muslimheritage.v4i2.1766; Kambali Kambali, Ilma Ayunina, dan Akhmad Mujani, "Tujuan Pendidikan Islam dalam Membangun Karakter Siswa di Era Digital (Studi Analisis Pemikiran Pendidikan Islam Abuddin Nata)," Risâlab: Jurnal Pendidikan dan Studi Islam 5, no. 2, Sept (3 September 2019): 119, https://doi.org/10.31943/jurnal_risalah.v6i1.106.

32 Ary Antony Putra, "Konsep Pendidikan Agama Islam Perspektif Imam Al-Ghazali," Jurnal Pendidikan Agama Islam Al-Thariqah 1, no. 1 (2016): 41-54, https://doi.org/10.25299/althariqah.2016.vol1(1).617.

33 Undang-Undang Republik Indonesia Nomor 20 Tahun 2003 tentang Sistem Pendidikan Nasional.

34 Al-Ghazali, Ibya' Ulum al-Din, 2011, 1:60-73.

35 Ahmed Nafiu Arikewuyo, "A Comparative Study of al-Ghazali’s and Ibn Taymiyyah's Views on Sufism," International Journal of Islamic Thought 17 (2020): 15-24. 
of concepts about something that becomes an object, but science is essentially a witness (ma'rifah) of objects that are under their essence. The ethics that must be possessed by students are as follows: First, students must cleanse their soul from reprehensible behavior, character, and morals, because knowledge is a form of worship and the requirement for worship necessitate purification. Second, students should minimize their tendency towards worldly things and stay away from the influence of negative folk. Third, students must not underestimate knowledge and must also obey the teacher like a patient submits to a doctor. Fourth, students must focus on one teaching that is praised and approved by the teacher. Students, at the beginning of their studies, are prohibited from listening to different opinions of ulama' fiqh. Fifth, students must deepen the knowledge learned through various scientific disciplines. So that students know the goals and intentions of this knowledge. Sixth, students must learn in a gradual and structured manner. Seventh, students are not allowed to study science without knowing the pre-requisite knowledge. Eighth, students must know the causes that can lead them to the most important knowledge ('ilm al-mukasyafah). Ninth, students must aim to beautify the soul and decorate it with noble behavior to be closer to Allah. Tenth, students must give priority to knowledge over others. ${ }^{36}$

The ethics of religious teachers according to Imam Al-Ghazali are as follows: First, he must love his students as he loves his children. The Prophet Muhammad said: Verily I am to you like a father with his child. Second, the teacher must have sincerity. In teaching science, the teacher must not aim to gain rewards and gratitude. He must teach his students only because of Allah. Third, teachers must not tire of advising their students wisely. Fourth, the teacher must be able to prevent students from moral reproach in a subtle way. Fifth, teachers should not underestimate other fields of knowledge. Sixth, the teacher must provide lessons according to the levels of comprehension of his students. Seventh, the teacher must provide a clear understanding to students who are less intelligent and the teacher is prohibited from inculcating doubt and insecurity. Eighth, teachers must practice their knowledge. ${ }^{37}$

\section{ONTOLOGY (THE ESSENCE OF KNOWLEDGE) ACCORDING TO IMAM AL- GHAZALI}

It has been explained that a student will acquire true knowledge when both students and teachers can maintain their ethics and keep their souls clean. This is because, ontologically, science is light. According to al-Kindi, there are two kinds of human knowledge; First, sensory knowledge, namely human knowledge related to the shadow of an object that is stored in retentive faculty. The second is the science of reason which deals with universal and immaterial objects that are summarized through logic. This rational object of knowledge also deals with the abstraction of sensory objects. ${ }^{38}$ Ibn Sina stated that knowledge is a kind of human abstraction of the object. True knowledge, according to him, can be obtained through reason; it is the only means for humans to get to the truth. Besides that, through the holy spirit man can make direct contact with universal reason to gain knowledge. ${ }^{39}$ In line with Ibn

\footnotetext{
36 Al-Ghazali, Ihya' Ulum al-Din, 2011, 1:49-55.

${ }^{37}$ Al-Ghazali, 1:55-58.

38 Majid Fakhry, A History of Islamic Philosophy, 2 ed., Studies in Oriental Culture 5 (New York: Columbia Univ. Press, 1983), 116-17.

${ }^{39}$ Abu Ali Ibn Sina, Ahwal al-Nafs, trans. oleh M. S. Nasrullah (Bandung: Pustaka Hidayah, 2009), 167-68.
} 
Sina, Ibn Rusyd stated that science is the human conception of objects. This conception can be obtained through either the senses or an intellect. To obtain true knowledge, humans must use his logic. This is what is called a burbani. In addition, Ibn Sina also acknowledges the truth that comes from the Koran. ${ }^{40}$

Al-Ghazali had a different view from most Muslim scholars in the point of true knowledge. Like other Sufi scholars, Al-Ghazali argued that knowledge is light, not a pile of concepts that exist in the human mind. According to him, knowledge is one of the attributes of Allah which cannot be separated from the holiness of the essence of Allah. ${ }^{41}$ This opinion is following the al-Qur'an, surah Al-Anbiya', verse 4: "Muhammad said to them my Lord knows all the statements that exist on earth and in the sky. He is the One who is all-hearing and all-knowing." In the surah al-Baqarah, verse 154: "Allah knows everything that is stored in the heart". In Surah al-Taubat, verse 78: "He knows the secrets and whispers of unbelievers and knows everything unseen". These verses illustrate that knowledge is an attribute of Allah. Theologically, the relationship between the attribute and the essence (drat) of God cannot be separated, because the attribute is not God, but not others (biya la buwa, wala hiya ghairu bu). Furthermore, Imam Al-Ghazali, in his book Misykat al-Anwar, stated that the true light is Allah while the other light is majaz in nature which has no essence. Furthermore, Imam Al-Ghazali elaborated that light has several meanings; light for the common man is something that is visible and something else becomes visible, for the person of khawash light is the soul who can know (intellect) and for khawash al-khawash the light is Allah. This opinion is the result of Imam Al-Ghazali's interpretation of surah al-Nur verse $35{ }^{42}$

Etymologically, ilm means to know, the word ilm comes from the Arabic alima, ya'lamu, ilman which means "to know". The same with other Sufi scholars, Imam Al-Ghazali defines science as follows: "al-ilm huwa ma'rifat al-syai 'ala ma huwabibi". It means knowledge is ma'rifah (knowing in depth) of something correctly. The word ma'rifah in the terminology of the Sufis has a different meaning from the word 'alima or ra'a which means to know. Since ma'rifah occurs after the occurrence of knowing on living (musyahada), Imam Al-Ghazali stated that ma'rifab is witnessing firsthand (ithila) the secret of divine secrets and knowing about the sequence of everything that happens in the universe. ${ }^{44}$ For this reason, the above definition implies that science is a detailed knowledge of objects that are owned by the subject.

In the book Misykat al-Anwar, Imam Al-Ghazali further explained that the knowledge is God himself. The divine light (Allah) then illuminates the creature that He wants. Through his linguistic description, Imam Al-Ghazali argued that light is an expression for something that exists (wujud) by itself and because of Him another existence comes into being (mujud). ${ }^{45}$ Theologically, knowledge is one of the attributes of Allah. Al Ghazali stated: "Al-ilm buwa

${ }^{40}$ Fathul Mufid, "Epistemologi Mulla Sadra: Kajian Tentang Ilmu Husuli dan Ilmu Huduri” (Dissertation, Semarang, Pascasarjana UIN Walisongo, 2012), 1-5.

41 Al-Ghazali, Ibya' Ulum al-Din, 2011, 1:29.

42 Abu Hamid Muhammad Al-Ghazali, Miyskat al-Anwar wa Mashafat al-Asrar (Beirut: Alam al-Kutub, 1986), 79-94.

43 Al-Ghazali, Ibya' Ulum al-Din, t.t., 1:29. Futher elaboration see Al-Ghazali, "Bayan Syawahid al-Syar'i 'Ala Shihah Tariq Ahl al-Tasawuf fi Iktisab al-Ma'rifah", Ibya' Ulum al-Din, 2011, 8:22-25.

${ }^{44}$ Futher elaboration see Al-Ghazali, Ihya' Ulum al-Din, t.t., 3:22-25.

${ }^{45}$ Mehdi Hairi Yazdi, Ilmu Hudhuri: Prinsip-Prinsip Epistemologi dan Filsafat Islam (Bandung: Mizan, 1994), 3738. 
ma'rifah al-syai 'ala ma buwa bibi. Wabuwa min shifatillah ta'ala." "'t It means: Knowledge is ma'rifah (knowing in detail) according to something itself. It is from the nature of Allah the Highest. Knowledge belongs only to Allah, the knowledge possessed by creatures is an abundance of Allah's knowledge. That is why Imam Al-Ghazali, in the Misykat book, states explicitly that lucid knowledge comes from Allah (Light of heaven and earth) then hierarchically shines into the spirit of prophecy (prophetic ability), then into the spirit of al-fikr (analytical ability), then to the spirit of al-aqli (the ability to gather), then to the al-fictional spirit (the ability to abstract something) and finally the hasasiy spirit (the ability to recognize objects with the five senses). According to the al-Arif billah, the real light is Allah, while the rest of the light is only majazin nature. Al Ghazali stated: "anna al-nur al-Haq buwa Allah ta'ala wa anna isma al-nur li ghairibi majazun mabdhun la haqiqata labu.",

For Al-Ghazali, qalb/rub/aql/nafs essentially is one - namely a lathifah rubaniyah rubaniyah. It functions as a mirror which is capable of capturing the image of the thing. The higher the quality of the qalb/rub/aql/nafs, the more complex and complete the image of being captured by the qalb and vice versa. So according to Imam Al-Ghazali, knowledge is light. It cannot be limited by anything. It contains all the definitions of everything that is found whether it is in the form of actions, all causes and effects, all ideas, dreams, and everything else. ${ }^{48}$ Furthermore, Al-Ghazali explained about the gradations of the existence (the otherness than Allah). Every existence (al-manjudad) other than Allah has four levels: first, the form (existing) that is in laub al-mabfudr; second is the level of essential existence, third is imaginative; and the last one is the form of aqli; this last form can be recorded by human reason both abstract and concrete. ${ }^{49}$ From this explanation it is known that what is called empirical reality is an imaginative shadow that comes from the real reality (mujud baqiqi). The ultimate reality comes from the reality that is in laub al-mahfudz (Allah's knowledge). Due to the existing levels of manifestation of reality, the student must cleanse his soul to know the reality of the object at a higher and more valid level.

\section{EPISTEMOLOGY IN THE VIEW OF IMAM AL-GHAZALI}

According to Jujun Suriasumantri, each science possesses specific characteristics about its essence (ontology), how to obtain it (epistemology), and its use (axiology). ${ }^{50}$ Therefore, in discussing the philosophy of science these three important topics must be the focus of study. After the author explains the concept of the ontology of science, in this discussion the author discusses methods or ways of obtaining knowledge according to Imam Al-Ghazali.

Imam Al-Ghazali strongly encouraged students to seek knowledge. According to him, seeking knowledge is an important and very noble action. Imam Al-Ghazali gave a high value to science. This assessment is based on the arguments of al-Qur'an and al-Hadith as well as rational arguments. Imam Al-Ghazali quoted many verses of the Qur'an such as verse 11 of Surah al-Mujadalah, verse 18 of surah Ali Imran, verse 28 of surah Fathir and so forth. He

\footnotetext{
46 Al-Ghazali, Ihya' Ulum al-Din, t.t., 1:29.

47 Al-Ghazali, Miyskat al-Anwar wa Mashafat al-Asrar, 119.

${ }^{48}$ Mufid, "Epistemologi Mulla Sadra: Kajian Tentang Ilmu Husuli dan Ilmu Huduri," 148-49.

49 Al-Ghazali, Ibya' Ulum al-Din, t.t., 1:20.

${ }^{50}$ Jujun S. Suriasumantri, Filsafat Ilmu: Sebuab Pengantar Populer (Yogyakarta: Sinar Harapan, 1983), 105.
} 
also regularly cited multiple narrations of hadith, as well as statements of well-known Sufi axioms, relating to the virtue of science both on a theoretical and axiological level.

Furthermore, he provided a rational argument about the virtue of science. The primary virtue of knowledge is due to the necessity of the subject. Secondly, science can be a means to secure the happiness of others (something that is loved). This is why science is categorized as a very noble thing. ${ }^{51}$ Because knowledge is very noble and beneficial to humans, Al-Ghazali required people to seek knowledge. These obligations depend on needs. If knowledge is needed and must be owned by every individual, then that knowledge becomes a science that is fardhu 'ain. If this knowledge is needed in collective life, then the law is fardhu kifayah and seeking it is also kifayah. The categories of fardhu 'ain and kifayah are not only related to religious issues, but also depend on the needs and benefits of a person or group of both religious and worldly issues. The opinion of Imam Al-Ghazali is very different from the opinion of other scholars who often relate the law of seeking knowledge with the discipline of knowledge itself, not the ultimate goal of knowledge.

Furthermore, if this knowledge can be useful for improving the quality of life, then the law is sunnah. In general, Imam Al-Ghazali divided the object of knowledge into three; namely the knowledge of how to do something, the knowledge of how to leave something behind, and knowledge related to belief; knowledge that must be done; such as the science of purification, the knowledge of prayer, fasting and so on, while the science of leaving is the science related to prohibition and science related to shabada or the science of faith is a type of knowledge that must be believed ${ }^{52}$. Muslims have different demands toward knowledge. It is dependent on his situation and conditions. For example, a person who is mute does not need to learn about the prohibition of backbiting, a blind person does not need to learn the prohibition of seeing something that is forbidden, and so on. ${ }^{53}$

Imam Al-Ghazali stated that knowledge can be divided into two; namely knowledge of thariq al-dunya and knowledge of thariq al-akhirah. The science of thariq al-dunya is a science that addresses issues related to worldly goodness - such as architecture, commerce and arithmetic and so on. The knowledge of al-thariq al-akhirah is that which regulates and directs humans so that they are safe in the hereafter and obtain happiness with Allah. Knowledge of thariq alakbirab is divided into two; first, knowledge about how to manage and purify the heart which is called 'ilm al-mu'amalah. Second, 'ilm al-mukasyafah, namely knowledge that is a gift from Allah to the prophets, saints and holy people. This kind of knowledge can arise in the heart after a person has purified his soul. Personally, Imam Al-Ghazali testified in his autobiography that while undertaking a meditative 'uzlah (seclusion) for ten years, he experienced the opening of the hijab (mukasyafah) to know various objects that he had never experienced before. This science is the most valid science and there is no doubt at all and a convincing science (al- 'ilm al-yaqini.$^{54}$

\footnotetext{
${ }^{51}$ Al-Ghazali, Ihya' Ulum al-Din, t.t., 1:13.

52 Sajjad Rizvi, "Al-Ghazālī’s moderation in belief. Al-Iqtiṣād fì al-i tiqād," British Journal of Middle Eastern Studies 44, no. 1 (2 Januari 2017): 149-50, https://doi.org/10.1080/13530194.2016.1238593.

53 Al-Ghazali, Ihya' Ulum al-Din, t.t., 1:15-16.

54 Al-Ghazali, Al-Munqidz min al-Dhalal.
} 
Further, Imam Al-Ghazali explained the method to obtain the right knowledge. He rejected neither the Aristotelian empirical correspondence theory nor the Platonic theory of idealism. For him, both of them are the first step to secure the right knowledge. In his book al-Munqidz, min al-Dhalal, Imam Al-Ghazali criticized the ability of the senses to recognize objects. The senses possessed by humans have limitations, therefore the knowledge produced also has limitations. Likewise, human reason also has weaknesses and can be confused by feelings, therefore the knowledge produced by reason is also weak. In contrast to Islamic philosophers such as al-Kindi, Ibn Sina, and Ibn Rusyd - who all accepted the dual theory of truth (scientific truth and religious truth) - Imam Al-Ghazali believed in a single truth. Epistemologically, to obtain a single scientific truth, a student must apply two methods; the first is through being focused and serious in studying with the sanctity of the soul. Second, students must do riyadhah and mujahadab ${ }^{55}$.

Imam Al-Ghazali disagreed with an epistemology of empiricism and rationalism. For Al-Ghazali, there are two methods of obtaining knowledge: First, using istifada (utilizing reason) to understand reality using the power of reason (ma ustufida min al-'aql) which is called ilm ghair al-syar'iyyah and also utilizing reason to understand revelation (ma ustifida min alanbiya). This is through observations of the object. In observing objects, humans have different ways and abilities, so that the results of the accuracy of their knowledge are different. This kind of knowledge is known as knowledge obtained through reason (ma ustufida min al'aq $)^{56}$.

Furthermore, Imam Al-Ghazali criticized this kind of knowledge. He stated that the human ability to observe existence depended on the level of intelligence. A person who has sensory intelligence (ibsasi) is only able to recognize objects that can be captured by the five $\operatorname{senses}^{57}$. This intelligence is the lowest. The second is imaginative intelligence (fictional); namely the ability to abstract the recognizable image through the senses. The third is rational intelligence (aqi); namely intellectual abilities that can find out the meaning behind observation and imagination. This is the essence of a human. The fourth is the intelligence of thinking (fikri): namely high-level intellectual abilities. From this intelligence comes various creations and competencies in concocting various elements appropriately ${ }^{58}$. Lastly is the holy intelligence (prophetic intelligence) which is possessed by the prophets and some of the saints. This highest level of intelligence is beyond the power of reason (thur wara' al-aq). In this intelligence, a person will gain illumination, the provisions of the hereafter, knowledge related to the kingdom of heaven and earth, and even divine knowledge (al-ma'arif al-rabbaniyyab) which are impossible to be described by intelligence and thinking. ${ }^{59}$

55 Taraneh Wilkinson, "Moderation and Al-Ghazali in Turkey: Responses to Skepticism, Modernity, and Pluralism," American Journal of Islam and Society 32, no. 3 (2015): 29-43, https://doi.org/10.35632/ajiss.v32i3.269.

${ }^{56}$ Benaouda Bensaid dan Salah Machouche, "Education Piety: Special Reference to Abu Hamid al-Ghazali and Abdul Rahman Ibn Khaldun," dalam Global Perspectives on Teaching and Learning Paths in Islamic Education (IGI Global, 2020), 34-59.

${ }^{57}$ Muhammad Abul Quasem, "Al-Ghazāli’s evaluation of abu yazid al-bistāmi and his disapproval of the mystical concepts of union and fusion," Asian Philosophy 3, no. 2 (1 Oktober 1993): 143-64, https://doi.org/10.1080/09552369308575380.

${ }^{58}$ Joseph E. B. Lumbard, Ahmad Al-Ghazali, Remembrance, and the Metaphysics of Love (SUNY Press, 2016).

59 Al-Ghazali, Miyskeat al-Anwar wa Mashafat al-Asrar, 165-67. 
The second way to obtain knowledge is through the gift of Allah. This type of knowledge is referred to as ladunni knowledge, or ilm al-mukasyafah, which is the knowledge possessed by prophets, saints, and holy people as a gift from Allah, this knowledge is divine light plunging into the heart so that the heart can see the existence without the slightest doubt. This kind of knowledge arises in the heart after a Sufi has purifying his heart through performs riyadhah and mujahadah. This kind of knowledge is true knowledge because in it there is no doubt whatsoever. In other words, it is a convincing science (al-ilm al-yaqin $).{ }^{60}$

Furthermore, Al-Ghazali explained that the barriers (bijab) for humans to obtain correct knowledge are three; matter, a combination between light and matter, and pure light. He stated that atheists are veiled by their dirty souls and lust. They obey their lusts, are veiled by power, property, blind imitation of their ancestors. ${ }^{61}$ The second group was veiled by light and darkness; people who worship beauty, worshipers of fire, worshipers of stars, moon, and sun, and worshipers of pure light ${ }^{62}$. They believe in God, but God personifies imaginatively. This group also consists of religious people who believe that Allah can see, hear, speak, know, is powerful, wills, lives, etc. but they equate these qualities with those of beings. The last group is those who are close to Allah. Their awareness of other than Allah is lost because of the strong light of Allah because of their degree of baqa' fi Allah wa fana' an al-nafsibi. ${ }^{63}$

\section{AXIOLOGY OF SCIENCE ACCORDING TO IMAM AL-GHAZALI}

It has been explained that axiology is a major part of a discussion in the study of the philosophy of science. The study of axiology focuses on the discussion of the uses and benefits of science. To explain the axiological aspects of science, Imam Al-Ghazali explained that knowledge is of very high value because students who are seeking knowledge have a very noble degree as well ${ }^{64}$. Through knowledge humans can gain happiness and prosperity in the world and because of this the happiness of the hereafter will also be obtained. In other words, knowledge is positioned as a way to obtain happiness in the world and the hereafter. He stated ashlu al-sa'adah fi al-dunya wa al-netherah buwa al-ilm wa al-amal (the principal of the world and the hereafter is knowledge and charity). According to him, the hereafter is only obtained through charity and charity requires knowledge. That's why knowledge is very important to obtain the happiness of life in this world and the hereafter. ${ }^{65}$

Imam Al-Ghazali strongly emphasized the axiological aspect of science and this was reflected in the profile of the outcome learning from his Sufi education process ${ }^{66}$. The profile of graduates is the most important part of the education system today because the profile of graduates is an ideal description of the outcome of the learning process. In the modern world,

\footnotetext{
${ }^{60}$ Al-Ghazali, Al-Munqidz min al-Dhalal.

${ }^{61}$ Al-Ghazali, Miyskat al-Anwar wa Mashafat al-Asrar, 177-79.

62 Omar Al-Khateeb, "Sufism Methodology and Its Educational Applications," Journal of Studies in Education 10, no. 1 (2020): 65-76.

${ }^{63}$ Al-Ghazali, Miyskat al-Anwar wa Mashafat al-Asrar, 183-85.

${ }^{64}$ Mohammed Hassan Al-Awamreh, "Al-Imam Al-Ghazali’s View of Moral Education: Its Purposes and Pillars," US-China Education Review 6, no. 5 (2016): 311-17.

${ }^{65}$ Al-Ghazali, Ibya' Ulum al-Din, 2011, 1:13-14.

${ }^{66}$ Jon Hoover, "Free Will and Predestination in Islamic Thought: Theoretical Compromises in the Works of Avicenna, al-Ghazālī and Ibn 'Arabī," Islam and Christian-Muslim Relations 26, no. 4 (2 Oktober 2015): 516-18, https://doi.org/10.1080/09596410.2015.1053274.
} 
the profile of graduates is always linked to the work skills possessed by graduates. The profile of graduates of Imam Al-Ghazali's sufi education is ulama' afterlife (Ulama' al-Akhirat), namely Muslim scholars who have the competence of knowledge, attitude and charity as the five madzhab Imams (Imam Malik, Abu Hanifah, al-Syafi'i, Hanbali and Imam Sufyan al-Tsauri): According to him, the five scholars mentioned have main characteristics, namely; (1) Ulama' who are experts in worship ('abidan); (2) Ulama' who have zubud towards the world (zabidan); (3) Ulama' who are mastered how to obtain salvation in the hereafter; (4) Ulama' who understand deeply (faqib) about the benefit of creatures in the world; (5) Sincere ulama', ulama' who always hope the pleasure of Allah only. ${ }^{67}$

In detail, $\mathrm{Al}-\mathrm{Ghazali}$ mentioned the characteristics of ulama' afterlife as follows: first, they do not use knowledge to seek wealth in the world. This is because people know that the world has a lower value. Second, they are always oriented to gain useful knowledge in the hereafter and motivate obedience to Allah. Third, they do not like to boast in clothes, food, and other living accessories ${ }^{68}$. Fourth, they do not come in and out (approach) the rulers, they even tend to stay away from them. This is done to maintain a pure heart and independence in lifestyle. Fifth, ulama' akbirat are not quick to issue religious advice (fatwa). Sixth, they are more inclined towards inner knowledge; namely, knowledge related to how to clean the heart, know the science of the afterlife and have a strong will to know mukasyafah through mujahadah and riyadhah. Seventh, they always try to strengthen their religious beliefs because faith is the main asset for their religion. Eighth, they are very afraid of Allah. Ninth, they believe more in the knowledge that comes from their hearts rather than in the theoretical sciences. Tenth, they guard themselves against various bid'ab teachings. ${ }^{69}$

To become "scholars of the hereafter", students must focus and be serious in learning and carrying out noble morals. The kinds of moral behaviors that must be undertaken by students are as follows; first, students must always prioritize the cleanliness of the soul from disgraceful character, because the essence of knowledge is worship, prayer and a sincere approach to Allah ${ }^{70}$. Second, seekers of knowledge must reduce their proclivity towards worldly things, they have to move away from their family to be more focused on knowledge. Third, seekers of knowledge must not be arrogant towards knowledge and teachers. The student must submit to the teacher as a sick person surrenders to a doctor. Fourth, students must ensure a cautious distance from different opinions. Fifth, students must understand the ultimate goal of the knowledge being learned. Sixth, students must study regularly and in a structured manner. Seventh, students may not learn higher subjects until they have mastered the basic ones. Eighth, students must be able to improve the quality of their knowledge through showing good performance and deepening scientific arguments. Ninth, students must maintain the intention and purpose of learning only because of Allah. Tenth, students should not be deceived by the enjoyment of worldly knowledge. Because, the world is only a place,

${ }^{67}$ Al-Ghazali, Ibya' Ulum al-Din, t.t., 1:25.

${ }^{68}$ Umiarso Umiarso, "Transformation Into the 'God': Study of Critic-elaborative Axiology of Islamic Education with Philosophical Sufism,” Edukasi 17, no. 1 (2019): 294366.

${ }^{69}$ Al-Ghazali, Ibya' Ulum al-Din, t.t., 1:60-72.

70 Abdessamad Belhaj, "The First Islamic Reviver: Abū Ḥāmid al-Ghazālī and His Revival of the Religious Sciences," Islam and Christian-Muslim Relations 26, no. 3 (3 Juli 2015): 387-88, https://doi.org/10.1080/09596410.2014.989669. 
the body is transportation, while good deeds cause eternal happiness; namely the happiness of the hereafter. ${ }^{71}$

\section{CONCLUSION}

According to Imam Al-Ghazali, the concept of Sufi education for students can be summarized as follows: education is a process carried out by the teacher consciously and aimed to obtain true happiness (happiness in the hereafter). Education is not only limited to the transfer or transformation of knowledge but must reach the realm of affection (al-Hal) and must appear in the psychomotor realm in the form of good deeds. This concept is based on a very unique concept of science ontology and epistemology.

According to the Imam, ontologically knowledge is the illumination of the light of Allah. Therefore, knowledge becomes the cause for students to recognize objects and then science encourages them to take action under these objects. If it is known that the object is good, then the student undertakes it. If it otherwise, then the student should leave it. Due to this precept, Imam Al-Ghazali provided a nuanced code of ethics that must be undertaken by students and teachers (as folk who guide students). Epistemologically, knowledge can be obtained in two ways. First, pure and good moral behavior. Second, through mujahadah and riyadhah so that the heart becomes clean and holy. After this, the light of Allah will shine on the heart and the result is that a student will be able to perceive the reality of existence. Axiologically, knowledge that comes from this divine emanation will certainly give birth to the behavior of obedience to Allah and in turn will result in outcome learning that has a profile as someone knowledgeable, charitable, righteous, useful, and sincere because of Allah.

\section{REFERENCES}

Adib, Mohammad. Filsafat Ilmu: Ontologi, Epistemologi, Aksiologi, dan Logika Ilmu Pengetahuan. 2 ed. Yogyakarta: Pustaka Pelajar, 2010.

Adz-Dzahabi. Siyar A'lam Nubala'. Vol. 19. Beirut: Mu'asasah ar-Risalah, 2011.

Agus, Zulkifli. "Pendidikan Islam Dalam Perspektif Al-Ghazali." Raudhah Proud To Be Professionals: Jurnal Tarbiyah Islamiyah 3, no. 2 (17 Desember 2018): 21-38. https://doi.org/10.48094/raudhah.v3i2.28.

Al-Awamreh, Mohammed Hassan. "Al-Imam Al-Ghazali's View of Moral Education: Its Purposes and Pillars." US-China Education Review 6, no. 5 (2016): 311-17.

Al-Bukhori. Shabih al-Bukhori. Vol. 1. Beirut: Dar al-Fikri, 1981.

Al-Dimyathi, Muhammad Syatha. Kifayat al-Atqiya' wa Minhaj al-Ashfiya'. Semarang: Thoha Putra, t.t.

Al-Ghazali. Al-Munqidz min al-Dhalal. Egypt: Ali Shabib wa Auladuh, 1952.

—. Ibya' Ulum al-Din. Vol. 8. Arab Saudi: Dar al-Minhaj, 2011.

Ibya' Ulum al-Din. Vol. 1. Arab Saudi: Dar al-Minhaj, 2011.

Ibya' Ulum al-Din. Vol. 1. Beirut: Dar al-Fikri, t.t.

Ibya' Ulum al-Din. Vol. 3. Beirut: Dar al-Fikri, t.t.

Ibya' Ulum al-Din. Vol. 4. Beirut: Dar al-Fikri, t.t.

${ }^{71}$ Al-Ghazali, Ibya' Ulum al-Din, 2011, 1:62-67. 
Al-Ghazali, Abu Hamid Muhammad. Miyskat al-Anwar wa Mashafat al-Asrar. Beirut: Alam alKutub, 1986.

Ali, Mohammad. Ilmu dan Aplikasi Pendidikan. Bandung: Pedagogiana Press, 2007.

Al-Khateeb, Omar. "Sufism Methodology and Its Educational Applications." Journal of Studies in Education 10, no. 1 (2020): 65-76.

Alwizar, Alwizar. "Pemikiran Pendidikan Al-Ghazali." Potensia: Jurnal Kependidikan Islam 1, no. 1 (2 Juni 2015): 129-49.

Arikewuyo, Ahmed Nafiu. "A Comparative Study of al-Ghazali's and Ibn Taymiyyah's Views on Sufism." International Journal of Islamic Thought 17 (2020): 15-24.

Aslan Guemuesay, Ali. "Boundaries and knowledge in a Sufi Dhikr Circle." Journal of Management Development 31, no. 10 (19 Oktober 2012): 1077-89. https://doi.org/10.1108/02621711211281861.

As-Sarwani, Abdul Aziz Izzu Al-Din. Muqaddimah Misykat al-Anwar wa Mashafat al-Anwar. Beirut: Alam al-Kutub, t.t.

As-Subki, Tajuddin 'Abdul Wahab. Thabaqat asy-Syafi'iyah Kubro. Vol. 6. Beirut: Darul Kutub Ilmiyah, t.t.

Attaran, Mohammad. "Moral Education, Habituation, and Divine Assistance in View of Ghazali." Journal of Research on Christian Education 24, no. 1 (2 Januari 2015): 43-51. https://doi.org/10.1080/10656219.2015.1008083.

Bakker, Anton, dan Achmad Charris Zubair. Metodologi Penelitian Filsafat. Yogyakarta: Kanisius, 1994.

Belhaj, Abdessamad. "The First Islamic Reviver: Abū Hāamid al-Ghazālī and His Revival of the Religious Sciences." Islam and Christian-Muslim Relations 26, no. 3 (3 Juli 2015): 387-88. https://doi.org/10.1080/09596410.2014.989669.

Bensaid, Benaouda, dan Salah Machouche. "Education Piety: Special Reference to Abu Hamid al-Ghazali and Abdul Rahman Ibn Khaldun." Dalam Global Perspectives on Teaching and Learning Paths in Islamic Education, 34-59. IGI Global, 2020.

Bolandhematan, Keyvan. "Spiritual Education in Islamic Tradition: Revisiting Ghazali's 'Deliverance."' Religious Education 114, no. 2 (15 Maret 2019): 110-29. https://doi.org/10.1080/00344087.2018.1560585.

Fakhry, Majid. A History of Islamic Pbilosophy. 2 ed. Studies in Oriental Culture 5. New York: Columbia Univ. Press, 1983.

Hanani, Ahmad, dan Nur Hamidi. "Tasawuf Pendidikan: Dari Spiritualitas Manusia Menuju Insan Kamil." Jurnal Pendidikan Agama Islam 16, no. 1 (5 Juni 2019): 35-62. https://doi.org/10.14421/jpai.2019.161-03.

Hidayat, Ziaulhaq, dan Muzakkir Syahrul. "Indonesian Sufi in Malay World: A Preliminary Exploration with Reference to Tariqa Naqshbandiyya-Khalidiyya Babussalam (Tnkb)." Journal of Indonesian Islam 11, no. 1 (9 Juli 2017): 201-222-222. https://doi.org/10.15642/JIIS.2017.11.1.201-222.

Hoover, Jon. "Free Will and Predestination in Islamic Thought: Theoretical Compromises in the Works of Avicenna, al-Ghazālī and Ibn 'Arabī." Islam and Christian-Muslim Relations 26, no. 4 (2 Oktober 2015): https://doi.org/10.1080/09596410.2015.1053274. 
Ismail, Masthurhah, Puteri Rohani Megat Abdul Rahim, dan Muhammad Sufi Mohamad Yusoff. "Educational Strategies to Develop Discipline among Students from the Islamic Perspectives." Procedia - Social and Behavioral Sciences, The Proceedings of the 1st Evaluation of Learning for Performance Improvement International Conference 2013, 107 (11 Desember 2013): 80-87. https://doi.org/10.1016/j.sbspro.2013.12.402.

Kambali, Kambali, Ilma Ayunina, dan Akhmad Mujani. "Tujuan Pendidikan Islam dalam Membangun Karakter Siswa di Era Digital (Studi Analisis Pemikiran Pendidikan Islam Abuddin Nata)." Risâlab: Jurnal Pendidikan dan Studi Islam 5, no. 2, Sept (3 September 2019): 1-19. https://doi.org/10.31943/jurnal_risalah.v6i1.106.

Kurnanto, Muhammad Edi. "Pendidikan Dalam Pemikiran Al-Ghazali." Khatulistiwa 1, no. 2 $(1$

https://jurnaliainpontianak.or.id/index.php/khatulistiwa/article/view/189.

Lindholm, Charles. "Islam: Middle East." Dalam International Encyclopedia of the Social \& Behavioral Sciences (Second Edition), disunting oleh James D. Wright, 731-36. Oxford: Elsevier, 2015. https://doi.org/10.1016/B978-0-08-097086-8.84014-3.

Lumbard, Joseph E. B. Ahmad Al-Ghazali, Remembrance, and the Metaphysics of Love. SUNY Press, 2016.

Moedjiono, Imam. "Konsep Pendidikan Islam: Telaah Pemikiran Pendidikan Mohammad Natsir." El-Tarbawi 0, no. VI (2003): 46-61.

Mufid, Fathul. "Epistemologi Mulla Sadra: Kajian Tentang Ilmu Husuli dan Ilmu Huduri." Dissertation, Pascasarjana UIN Walisongo, 2012.

Putra, Ary Antony. "Konsep Pendidikan Agama Islam Perspektif Imam Al-Ghazali." Jurnal Pendidikan Agama Islam Al-Thariqah 1, no. 1 (2016): 41-54. https://doi.org/10.25299/althariqah.2016.vol1(1).617.

Quasem, Muhammad Abul. "Al-Ghazāli's evaluation of abu yazid al-bistāmi and his disapproval of the mystical concepts of union and fusion." Asian Pbilosophy 3, no. 2 (1 Oktober 1993): 143-64. https://doi.org/10.1080/09552369308575380.

Rayan, Sobhi. "The Stage-Beyond-the-Intellect as a Method of Research in al-Ghazali's Theory." Medieval Mystical Theology 22, no. 1 (1 Juni 2013): 59-73. https://doi.org/10.1179/2046572613Z.0000000004.

Rizvi, Sajjad. "Al-Ghazālī’s moderation in belief. Al-Iqtișād fī al-i tiqād." British Journal of Middle Eastern Studies 44, no. 1 (2 Januari 2017): 149-50. https://doi.org/10.1080/13530194.2016.1238593.

Rubaidi, Rubaidi. "Pengarusutamaan Nilai-Nilai Sufisme dalam Pendidikan Islam Indonesia Kontemporer." Jurnal Pendidikan Agama Islam (Journal of Islamic Education Studies) 8, no. 1 (31 Juli 2020): 21-38. https://doi.org/10.15642/jpai.2020.8.1.21-38.

Rusydi, Ibnu. "Paradigma Pendidikan Agama Integratif-Transformatif." Jurnal Pendidikan Islam 1, no. 1 (2011): 105-20. https://doi.org/10.14421/jpi.2011.11.105-120.

Sina, Abu Ali Ibn. Ahwal al-Nafs. Diterjemahkan oleh M. S. Nasrullah. Bandung: Pustaka Hidayah, 2009.

Sokolow, Moshe. "Knowledge and Action, Reason and Habit, in Jewish and Muslim Philosophies of Education." Journal of Research on Christian Education 22, no. 1 (1 Januari 2013): 21-29. https://doi.org/10.1080/10656219.2013.768104. 
Sulistyawati, Ririn Afrian, Probosuseno, dan Sri Setiyarini. "Dhikr Therapy for Reducing Anxiety in Cancer Patients." Asia-Pacific Journal of Oncology Nursing 6, no. 4 (2019): 41116. https://doi.org/10.4103/apjon.apjon_33_19.

Suriasumantri, Jujun S. Filsafat Ilmu: Sebuah Pengantar Populer. Yogyakarta: Sinar Harapan, 1983.

Sutopo, Heribertus. Pengantar Penelitian Kualitatif: Dasar-Dasar Teoritis dan Praktis. Surakarta: Pusat Penelitian Universitas Sebelas Maret, 1988.

Syaifudin, Roziq. "Epistemologi Pendidikan Islam Dalam Kacamata Al-Ghazali Dan Fazlur Rahman.” Epistemé: Jurnal Pengembangan Ilmu Keislaman 8, no. 2 (7 Desember 2013): 323-46. https://doi.org/10.21274/epis.2013.8.2.323-346.

Umiarso, Umiarso. "Transformation Into the 'God': Study of Critic-elaborative Axiology of Islamic Education with Philosophical Sufism.” Edukasi 17, no. 1 (2019): 294366.

Wilkinson, Taraneh. "Moderation and Al-Ghazali in Turkey: Responses to Skepticism, Modernity, and Pluralism." American Journal of Islam and Society 32, no. 3 (2015): 29-43. https://doi.org/10.35632/ajiss.v32i3.269.

Yazdi, Mehdi Hairi. Ilmu Hudhuri: Prinsip-Prinsip Epistemologi dan Filsafat Islam. Bandung: Mizan, 1994.

Zaim, Muhammad. “Tujuan Pendidikan Perspektif Al-Qur'an Dan Hadits (Isu Dan Strategi Pengembangan Pendidikan Islam)." Muslim Heritage 4, no. 2 (30 Desember 2019). https://doi.org/10.21154/muslimheritage.v4i2.1766. 